\title{
Influences of stocking density and dietary probiotic supplementation on growing Japanese quail performance
}

\author{
KHALID M. MAHROSE ${ }^{1}$, MAHMOUD ALAGAWANY ${ }^{1}$, MOHAMED E. ABD EL- \\ HACK ${ }^{1}$, SAMIR A. MAHGOUB ${ }^{2}$ and FATEN A. M. ATTIA ${ }^{3}$ \\ ${ }^{1}$ Department of Poultry, Faculty of Agriculture, Zagazig University, 44511, Zagazig, Egypt \\ ${ }^{2}$ Microbiology Department, Faculty of Agriculture, Zagazig University, 44519, Zagazig, Egypt \\ ${ }^{3}$ Animal Production Department, Faculty of Agriculture, Suez Canal University, 42524, Ismailia, Egypt \\ Manuscript received on June 16, 2018; accepted for publication on July 30, 2018
}

\begin{abstract}
How to cite: MAHROSE KM, ALAGAWANY M, ABD EL-HACK ME, MAHGOUB SA AND ATTIA FAM. 2019. Influences of stocking density and dietary probiotic supplementation on growing Japanese quail performance. An Acad Bras Cienc 91: e20180616. DOI 10.1590/0001-3765201920180616.
\end{abstract}

\begin{abstract}
This study investigated the effects of stocking density and dietary supplementation of probiotic (Lactobacillus) on growth, traits of carcass, lymphoid organs and intestinal microbial count of Japanese quail. Quail chicks (one week old) were randomly allotted to 6 groups in a $2 \times 3$ factorial experiment included 2 levels of stocking density (100, and $75 \mathrm{~cm} 2 / \mathrm{bird})$ and 3 levels of probiotic $(0.00,0.02$ and 0.04 $\mathrm{g} / \mathrm{kg}$ diet). Quail reared at $100 \mathrm{~cm} 2 /$ bird showed significantly the highest body weight and daily gain. Quail reared at $75 \mathrm{~cm} 2 /$ bird had significantly the lower average of feed consumption and the best ratio of feed conversion. Increasing level of probiotic up to $0.04 \mathrm{~g} / \mathrm{kg}$ led to a significant decrease in dressing percentage by about $2.7 \%$ compared to the control. Interaction effect was insignificant on carcass traits studied except for liver percentage which was significantly higher for birds fed diet supplemented with probiotic at $0.04 \mathrm{~g} / \mathrm{kg}$ of diet and reared at $100 \mathrm{~cm} 2 /$ bird. Rearing quail at $100 \mathrm{~cm} 2 /$ bird stocking density significantly increased bursa weight. Birds fed diet supplemented with probiotic at $0.02 \mathrm{~g} / \mathrm{kg}$ of diet and reared at $100 \mathrm{~cm} 2 /$ bird showed significantly the highest $(\mathrm{p}=0.043)$ spleen weight when compared with the other groups. In conclusion, the low $(100 \mathrm{~cm} 2 /$ bird $)$ stocking density was sufficient to give better performance of Japanese quail than the other group. Probiotic supplementation diminished the stressful effect of crowding on growing Japanese quail.
\end{abstract}

Key words: stocking density, probiotic, growth, immunology, microbial count, quail.

\section{INTRODUCTION}

Stocking density is necessary factor influencing poultry well-being, welfare, health and performance as well (Houshmand et al. 2012. El-Gogary et al. 2015). The influence of stocking density of different

Correspondence to: Mohamed Ezzat Abd El-Hack

E-mail: dr.mohamed.e.abdalhaq@gmail.com

ORCID: http://orcid.org/0000-0002-2831-8534 poultry species on growth performance had generated considerable interest last years (AbdelAzeem 2010). Different stocking densities were used around the world depending on the system of productive (Buijs et al. 2009). But increasing stocking density could make stress and deleterious impacts on poultry immunity and performance, especially during the growing period (Askar and Assaf 2004). The use of probiotic to quail 
feed is one of the strategies to enhance nutrients bioavailability and digestibility (Abd El-Hack et al. 2017. Alagawany et al. 2018). Many investigations confirmed the beneficial impacts of probiotics on growth, intestinal microflora, enhancing immunity function and carcass yield of poultry (Molnar et al. 2011. Ashour et al. 2015. Alagawany et al. 2016). Therefore, the objective of the present study was to investigate the influence of stocking density and dietary addition of Lactobacillus, as probiotic, on growth, carcass criteria, lymphoid organs and microbial count in the intestine of meat-type Japanese quail.

\section{MATERIALS AND METHODS}

\section{ANIMAL AND DIETS}

All procedures of the experiment were performed with reference to the Committee of Local Experimental Animal Care and approved by ethics of our Poultry Department institutional committee, Agriculture College, University of Zagazig, Egypt. Quail chicks were randomly allotted to six treatment groups in a factorial design $(2 \times 3)$, involving two density levels (100 and $75 \mathrm{~cm}^{2} /$ bird) and three levels of Lactobacillus (0.00, 0.02 and $0.04 \mathrm{~g} / \mathrm{kg}$ ) to evaluate the influences of stocking density, probiotic addition and their interactions on quail growth, carcass traits, lymphoid organs and intestinal bacterial count of growing Japanese quail.

Six hundreds and seventy-five of chicks oneweek old were randomly allotted to two main groups according to stocking density level, the $1^{\text {st }}$ group had 315 birds and the $2^{\text {nd }}$ one had 360 birds. Each experimental group of stocking density was sub-divided into 3 sub-groups according to probiotic supplementation level (15 or 20 chicks/ replicate). The current work was performed in an open house type under Egyptian summer conditions. A cage $(50 \times 30 \times 50 \mathrm{~cm})$ was used to house each replicate. Birds were subjected to 23 $\mathrm{h}$ light: $1 \mathrm{~h}$ dark, fed ad-libitum and feed and fresh water were available during the experiment. To cover nutrient requirements of meat-type quail, the basal diet was formulated according to NRC (1994) as presented in Table I.

TABLE I

Feed ingredients and chemical analysis of growing Japanese quail basal diet.

\begin{tabular}{|c|c|}
\hline Item & The basal diet \\
\hline \multicolumn{2}{|c|}{ Ingredients composition [ $\mathrm{g} / \mathrm{k}$; as-fed basis] } \\
\hline Maize & 525 \\
\hline Soybean meal & 382 \\
\hline Maize gluten meal (60\%) & 43.0 \\
\hline Vegetable oil & 16.0 \\
\hline Di-calcium phosphate & 16.0 \\
\hline Limestone & 9.0 \\
\hline $\mathrm{NaCl}$ & 3.0 \\
\hline Premix ${ }^{\#}$ & 3.0 \\
\hline L-lysine & 0.3 \\
\hline DL methionine & 0.7 \\
\hline Choline chloride & 2.0 \\
\hline \multicolumn{2}{|c|}{ Chemical analysis $(\mathrm{g} / \mathrm{kg})^{\# \#}$} \\
\hline $\mathrm{CP}$ & 241.5 \\
\hline $\mathrm{ME} \mathrm{MJ} / \mathrm{kg}$ & 12.15 \\
\hline $\mathrm{Ca}$ & 8.0 \\
\hline Avail, $\mathrm{P}$ & 4.6 \\
\hline Lysine & 13.1 \\
\hline Methionine & 5.0 \\
\hline Methionine+ Cystine & 8.2 \\
\hline
\end{tabular}

"Vitamin and Mineral premix, each 1 kg consists of: Vit A 12000, 000 IU; Vit D, 2000, 000 IU; Vit. E. 10g; Vit k 2 g; Vit B, 1000 mg; Vit $\mathrm{B}_{2}, 49 \mathrm{~g}$; Vit B, $105 \mathrm{~g}$; Vit B $12,10 \mathrm{mg}$; Pantothenic acid, $10 \mathrm{~g}$; Niacin, $20 \mathrm{~g}$, Folic acid, 1000 mg ; Biotin, 50 g; Choline Chloride, $500 \mathrm{mg}$, Fe, 30 g; Mn, 40 g; Cu, 3 g; Co, 200 mg; Si, 100 mg and Zn, 45 g.

\#Calculated according to NRC (1994). 


\section{COLLECTION OF DATA AND CALCULATION}

Parameters of growth performance (body weight, daily body weight gain feed intake, and feed conversion ratio) and carcass traits were determined and calculated according to El-Kholy et al. (2018).

\section{BACTERIAL COUNT}

Samples of the excreta from ceca and ileum (3 birds/ treatment), were subjected to microbiological investigations at 42 days of age. Samples were preserved in $5 \mathrm{~mL}$ sterile eppendorf tubes and processed immediately for microbiological studies. Total bacterial count (TBC), total lactobacilli count (TLC), coliforms and E. coli in caecum and ileums were determined according to Abd El-Hack et al. (2015). Before statistical analysis, number of bacterial group was transferred to Log number.

\section{STATISTICS}

Using $3 \times 2$ factorial design, data were analyzed statistically according to model: $\mathrm{Y}_{\mathrm{ijk}}=\mu+\mathrm{P}_{\mathrm{j}}+\mathrm{S}_{\mathrm{i}}$ $+\mathrm{PS}_{\mathrm{ij}}+\mathrm{e}_{\mathrm{ijk}}$

Where: $\mathrm{Y}_{\mathrm{ijk}}=$ an observation, $\mu=$ overall mean, $\mathrm{P}_{\mathrm{j}}=$ probiotic level effect $(\mathrm{j}=0,0.02$ and $0.04), S_{i}=$ stocking density levels effect $(i=100$ and 75), $\mathrm{PS}_{\mathrm{ij}}=$ the interaction between stocking density and probiotic levels and $\mathrm{e}_{\mathrm{ijk}}=$ random error. Using Duncan's new multiple rang test, differences among means under the same factor were examined (Duncan 1955).

\section{RESULTS}

\section{GROWTH PERFORMANCE}

Results of quail growth as impacted by probiotic bacteria supplementation, stocking density and their interactions are found in Table II. Body weight, daily weight gain, feed conversion ratio and daily feed consumption were insignificantly affected by dietary probiotic supplementation, except for feed consumption and conversion at 1-3 weeks of age. Birds fed diet supplemented with probiotic at $0.02 \mathrm{~g} / \mathrm{kg}$ of diet consumed significantly $(p \leq 0.05)$ less feed and had significantly $(p \leq 0.01)$ the best feed conversion. With regard to stocking density impact on growth performance, results in Table II, indicate that quail reared at stocking density of $100 \mathrm{~cm}^{2} /$ bird (15 bird/cage) showed statistically ( $p \leq 0.01)$ higher body weight (6 wks) and daily body weight gain (3-6 \& 1-6 wks) than the other group. However, quail reared at stocking density of $75 \mathrm{~cm}^{2} /$ bird (20 bird /cage) had significantly ( $p$ $\leq 0.01$ ) lowest averages of consumed feed at all periods studied and significantly $(p \leq 0.01)$ best values of feed conversion at 1-6 weeks of the age. Concerning the combination effect between probiotic supplementation and stocking density, results found in Table II showed that the interaction was insignificant, except for daily body weight gain at 3-6 weeks of the age and feed intake at 1-3 weeks of the age.

\section{CARCASS TRAITS}

As illustrated in Table III, it was found that increasing dietary level of probiotic from 0.00 to $0.04 \mathrm{~g} / \mathrm{kg}$ led to significant $(p \leq 0.05)$ depression in dressing percentage. Stocking density did not change carcass traits. Interaction effect was insignificant on studied carcass traits, except for liver percentage which was higher $(p \leq 0.05)$ in birds fed the diet supplemented with probiotic at $0.04 \mathrm{~g} / \mathrm{kg}$ of diet and reared at stocking density of $100 \mathrm{~cm}^{2} /$ bird in comparison with those of the other groups.

\section{LYMPHOID ORGANS}

Data presented in Table IV clearly indicated that lymphoid organs (Spleen, thymus and bursa of Fabricius) were insignificantly changed by dietary supplementation of probiotic. Rearing quail at the lower stocking density increased $(p \leq 0.05)$ bursa weight. Quail fed diet supplemented with probiotic 
TABLE II

Growth performance of Japanese quail as affected by probiotic bacteria supplementation, stocking density and their interaction during 1-6 weeks of age.

\begin{tabular}{|c|c|c|c|c|c|c|c|c|c|c|c|c|}
\hline \multirow{2}{*}{ Item } & \multicolumn{3}{|c|}{ LBW (g) } & \multicolumn{3}{|c|}{ DBWG (g/bird/day) } & \multicolumn{3}{|c|}{ FC (g/bird/day) } & \multicolumn{3}{|c|}{$\begin{array}{c}\text { FCR } \\
\text { (g feed/g gain) }\end{array}$} \\
\hline & 1 wk & $\begin{array}{c}3 \\
\text { wks }\end{array}$ & $\begin{array}{c}6 \\
\text { wks }\end{array}$ & $\begin{array}{l}1-3 \\
\text { wks }\end{array}$ & $\begin{array}{l}3-6 \\
\text { wk }\end{array}$ & $\begin{array}{l}1-6 \\
\text { wk }\end{array}$ & $\begin{array}{l}1-3 \\
\text { wk }\end{array}$ & $\begin{array}{l}3-6 \\
\text { wk }\end{array}$ & $\begin{array}{l}1-6 \\
\text { wk }\end{array}$ & $\begin{array}{l}1-3 \\
\text { wk }\end{array}$ & $\begin{array}{l}3-6 \\
\text { wk }\end{array}$ & $\begin{array}{l}1-6 \\
\text { wk }\end{array}$ \\
\hline
\end{tabular}

Main effects:

"Probiotic $[\mathrm{g} / \mathrm{kg}]$ :

$\begin{array}{lllllllllllll}0.00 & 21.4 & 75.3 & 175.8 & 3.9 & 4.8 & 4.4 & 12.5^{\mathrm{ab}} & 22.7 & 17.6 & 3.25^{\mathrm{b}} & 4.76 & 4.00 \\ 0.02 & 21.8 & 74.5 & 177.0 & 3.8 & 4.9 & 4.4 & 11.8^{\mathrm{b}} & 22.7 & 17.2 & 3.13^{\mathrm{b}} & 4.68 & 3.90 \\ 0.04 & 22.0 & 72.3 & 179.0 & 3.6 & 5.1 & 4.5 & 12.8^{\mathrm{a}} & 23.5 & 18.2 & 3.56^{\mathrm{a}} & 4.64 & 4.05\end{array}$

"\#ensity:

\begin{tabular}{|c|c|c|c|c|c|c|c|c|c|c|c|}
\hline $100 \mathrm{~cm}^{2} /$ bird & 21.4 & 75.0 & 182.4 & 3.8 & 5.1 & 4.6 & 13.2 & 23.8 & 18.5 & 3.45 & 4.67 \\
\hline $75 \mathrm{~cm}^{2} /$ bird & 22.1 & 73.1 & 172.1 & 3.7 & 4.7 & 4.3 & 11.6 & 22.2 & 16.9 & 3.18 & 4.72 \\
\hline
\end{tabular}

Interaction effect

\begin{tabular}{|c|c|c|c|c|c|c|c|c|c|c|c|c|c|}
\hline \multirow[t]{2}{*}{ Probiotic } & \multicolumn{13}{|l|}{ Density } \\
\hline & $\begin{array}{l}100 \\
\mathrm{~cm}^{2} / \\
\text { bird }\end{array}$ & 21.3 & 77.8 & 182.8 & 4.0 & $5.0^{\mathrm{ab}}$ & 4.6 & $13.2^{\mathrm{a}}$ & 23.5 & 18.4 & 3.28 & 4.71 & 3.99 \\
\hline 0.00 & $\begin{array}{c}75 \mathrm{~cm}^{2} / \\
\text { bird }\end{array}$ & 21.5 & 72.9 & 168.9 & 3.7 & $4.6^{\mathrm{bc}}$ & 4.2 & $11.8^{\mathrm{b}}$ & 22.0 & 16.9 & 3.21 & 4.81 & 4.01 \\
\hline \multirow{2}{*}{0.02} & $\begin{array}{l}100 \\
\mathrm{~cm}^{2} / \\
\text { bird }\end{array}$ & 21.3 & 73.6 & 185.1 & 3.7 & $5.3^{\mathrm{a}}$ & 4.7 & $12.1^{\mathrm{b}}$ & 23.8 & 17.9 & 3.25 & 4.48 & 3.84 \\
\hline & $\begin{array}{c}75 \mathrm{~cm}^{2} / \\
\text { bird }\end{array}$ & 22.3 & 75.5 & 168.8 & 3.8 & $4.44^{\mathrm{c}}$ & 4.2 & $11.5^{\mathrm{b}}$ & 21.6 & 16.5 & 3.01 & 4.88 & 3.96 \\
\hline \multirow{2}{*}{0.04} & $\begin{array}{l}100 \\
\mathrm{~cm}^{2} / \\
\text { bird }\end{array}$ & 21.7 & 73.7 & 179.4 & 3.7 & $5.0^{\mathrm{ab}}$ & 4.5 & $14.2^{\mathrm{a}}$ & 24.2 & 19.12 & 3.82 & 4.81 & 4.26 \\
\hline & $\begin{array}{c}75 \mathrm{~cm}^{2} / \\
\text { bird }\end{array}$ & 22.3 & 71.0 & 178.5 & 3.5 & $5.1^{\mathrm{a}}$ & 4.5 & $11.4^{\mathrm{b}}$ & 22.9 & 17.1 & 3.30 & 4.48 & 3.85 \\
\hline \multicolumn{2}{|c|}{ SEM } & 0.16 & 0.72 & 1.88 & 0.06 & 0.09 & 0.05 & 0.27 & 0.30 & 0.26 & 0.07 & 0.07 & 0.05 \\
\hline \multicolumn{14}{|c|}{$\begin{array}{c}\text { Two ways ANOVA } \\
\text { probability }\end{array}$} \\
\hline \multicolumn{2}{|c|}{ Probiotic } & 0.302 & 0.147 & 0.619 & 0.111 & 0.200 & 0.701 & 0.028 & 0.290 & 0.083 & 0.007 & 0.772 & 0.393 \\
\hline \multicolumn{2}{|c|}{ Density } & 0.065 & 0.145 & 0.002 & 0.082 & 0.008 & 0.001 & 0.000 & 0.003 & 0.000 & 0.012 & 0.688 & 0.323 \\
\hline \multicolumn{2}{|c|}{ Probiotic $\times$ Density } & 0.541 & 0.101 & 0.071 & 0.201 & 0.033 & 0.062 & 0.029 & 0.788 & 0.658 & 0.181 & 0.132 & 0.074 \\
\hline
\end{tabular}

LBW: Live body weight, DBWG: Daily body weight gain, FC: Feed consumption, FCR: Feed conversion ratio.

${ }^{\#}$ Lactobacilli concentration: $1 \times 10^{9}$ Lactobacilli/ g.

\#\# Density: 100 and $75 \mathrm{~cm}^{2} /$ bird for 15 bird/cage and 20 bird/cage, respectively. 
TABLE III

Carcass traits of Japanese quail as affected by stocking density and dietary probiotic bacteria supplementation at 42 days of age.

\begin{tabular}{|c|c|c|c|c|c|c|c|}
\hline \multirow{2}{*}{\multicolumn{2}{|c|}{ Items }} & \multicolumn{6}{|c|}{ Carcass traits $(\%)$} \\
\hline & & Dressed in & Dressed out & Giblets & Liver & Gizzard & Heart \\
\hline \multicolumn{8}{|c|}{ Main effects: } \\
\hline \multicolumn{8}{|c|}{ "Probiotic $[\mathrm{g} / \mathrm{kg}]$ : } \\
\hline & 00 & $82.30^{\mathrm{a}}$ & $17.70^{\mathrm{b}}$ & 4.93 & 2.54 & 1.42 & 0.97 \\
\hline & 02 & $82.66^{\mathrm{a}}$ & $17.34^{\mathrm{b}}$ & 5.25 & 2.76 & 1.53 & 0.97 \\
\hline & 04 & $80.08^{\mathrm{b}}$ & $19.92^{\mathrm{a}}$ & 5.17 & 2.90 & 1.42 & 0.85 \\
\hline \multicolumn{8}{|c|}{ "\# Density: } \\
\hline & $\mathrm{m}^{2} / \mathrm{bird}$ & 81.28 & 18.72 & 5.02 & 2.72 & 1.39 & 0.91 \\
\hline & $\mathrm{n}^{2} / \mathrm{bird}$ & 82.08 & 17.92 & 5.21 & 2.74 & 1.52 & 0.95 \\
\hline \multicolumn{8}{|c|}{ Interaction effect } \\
\hline Probiotic & Density & & & & & & \\
\hline \multirow{2}{*}{0.00} & $100 \mathrm{~cm}^{2} / \mathrm{bird}$ & 81.69 & 18.31 & 4.56 & $2.26^{\mathrm{b}}$ & 1.35 & 0.95 \\
\hline & $75 \mathrm{~cm}^{2} /$ bird & 82.92 & 17.08 & 5.29 & $2.81^{\mathrm{a}}$ & 1.48 & 1.00 \\
\hline \multirow{2}{*}{0.02} & $100 \mathrm{~cm}^{2} / \mathrm{bird}$ & 82.48 & 17.52 & 5.37 & $2.89^{\mathrm{a}}$ & 1.54 & 0.95 \\
\hline & $75 \mathrm{~cm}^{2} /$ bird & 82.84 & 17.16 & 5.13 & $2.63^{\mathrm{ab}}$ & 1.52 & 0.99 \\
\hline \multirow{2}{*}{0.04} & $100 \mathrm{~cm}^{2} / \mathrm{bird}$ & 79.68 & 20.32 & 5.11 & $3.00^{\mathrm{a}}$ & 1.28 & 0.84 \\
\hline & $75 \mathrm{~cm}^{2} /$ bird & 80.48 & 19.52 & 5.22 & $2.79^{\mathrm{a}}$ & 1.57 & 0.86 \\
\hline & $\mathrm{EM}$ & 0.45 & 0.21 & 0.09 & 0.08 & 0.04 & 0.03 \\
\hline \multicolumn{8}{|c|}{ Two ways ANOVA probability } \\
\hline & jiotic & 0.044 & 0.041 & 0.277 & 0.103 & 0.408 & 0.143 \\
\hline & nsity & 0.336 & 0.546 & 0.256 & 0.831 & 0.102 & 0.520 \\
\hline & $\times$ Density & 0.907 & 0.147 & 0.086 & 0.039 & 0.269 & 0.979 \\
\hline
\end{tabular}

${ }^{\#}$ Lactobacilli concentration: $1 \times 10^{9}$ Lactobacilli/ g.

\#\# Density: 100 and $75 \mathrm{~cm}^{2} /$ bird for $15 \mathrm{bird} /$ cage and $20 \mathrm{bird} /$ cage, respectively.

at $0.02 \mathrm{~g} / \mathrm{kg}$ of diet and reared at stocking density of $100 \mathrm{~cm}^{2} /$ bird showed significantly $(p \leq 0.05)$ the highest spleen weight $(0.19 \mathrm{~g})$ when compared with those of the other groups.

\section{MICROBIOLOGICAL FINDINGS}

At day 42, in comparison with un-supplemented group, total bacterial count (TBC) was increased in the small intestine and cecum of birds by supplemental probiotic through reducing coliforms counts and Escherichia coli populations and the increment in total Lactobacilli count (TLC) populations ( $p \leq 0.05$ ) (Figures $1 \& 2)$. Stocking density did not have any significant impact on the number of bacterial populations. Results revealed that maximum CFU of TLC might be recorded by dietary supplementation of probiotics with level of $0.04 \mathrm{~g} / \mathrm{kg}$ of diet and stocking density of 100 $\mathrm{cm}^{2} /$ birds (Fig. 1). However, the minimum CFU of colifroms and $E$. coli might be achieved with 0.04 $\mathrm{g} / \mathrm{kg}$ of dietary supplementation probiotic.

\section{DISCUSSION}

\section{GROWTH PERFORMANCE}

Results of the current work are in line with VargasRodriguez et al. (2013) who claimed that growth of broilers did not affect by dietary supplementation of probiotic. In addition, Ashour et al. (2015) 
TABLE IV

Lymphoid organs of Japanese quails as affected by stocking density and dietary probiotic bacteria at 42 days of age.

\begin{tabular}{|c|c|c|c|}
\hline \multirow{2}{*}{ Items } & \multicolumn{3}{|c|}{ Lymphoid organs (g) } \\
\hline & Spleen & Thymus & Bursa \\
\hline \multicolumn{4}{|l|}{ Main effects: } \\
\hline \multicolumn{4}{|l|}{ "Probiotic [g/kg]: } \\
\hline 0.00 & 0.14 & 0.58 & 0.20 \\
\hline 0.02 & 0.15 & 0.55 & 0.19 \\
\hline 0.04 & 0.10 & 0.55 & 0.17 \\
\hline \multicolumn{4}{|l|}{ 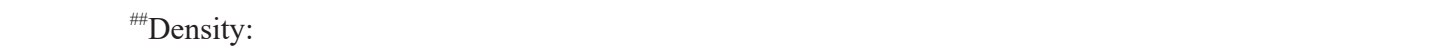 } \\
\hline $100 \mathrm{~cm}^{2} / \mathrm{bird}$ & 0.15 & 0.57 & 0.22 \\
\hline $75 \mathrm{~cm}^{2} /$ bird & 0.11 & 0.55 & 0.16 \\
\hline \multicolumn{4}{|l|}{ Interaction effect } \\
\hline Probiotic & & & \\
\hline 0.00 & $0.10^{\mathrm{ab}}$ & 0.59 & 0.18 \\
\hline $75 \mathrm{~cm}^{2} /$ bird & $0.18^{\mathrm{a}}$ & 0.57 & 0.21 \\
\hline 0.02 & $0.19^{\mathrm{a}}$ & 0.61 & 0.24 \\
\hline $75 \mathrm{~cm}^{2} /$ bird & $0.10^{\mathrm{ab}}$ & 0.49 & 0.14 \\
\hline \multirow{3}{*}{$\begin{array}{l}100 \mathrm{~cm}^{2} / \text { bird } \\
75 \mathrm{~cm}^{2} / \text { bird } \\
\text { SEM }\end{array}$} & $0.14^{\mathrm{ab}}$ & 0.50 & 0.23 \\
\hline & $0.06^{\mathrm{c}}$ & 0.60 & 0.12 \\
\hline & 0.02 & 0.04 & 0.02 \\
\hline \multicolumn{4}{|l|}{$\begin{array}{l}\text { Two ways ANOVA } \\
\text { probability }\end{array}$} \\
\hline Probiotic & 0.407 & 0.952 & 0.738 \\
\hline Density & 0.232 & 0.873 & 0.037 \\
\hline Probiotic $\times$ Density & 0.043 & 0.665 & 0.085 \\
\hline
\end{tabular}

\# Lactobacilli concentration: $1 \times 10^{9}$ Lactobacilli / g.

\#\# Density: 100 and $75 \mathrm{~cm}^{2} /$ bird for 15 bird/cage and 20 bird/cage, respectively.

found no differences in body weight and weight gain of broilers due to dietary supplementation of dried whey containing Lactobacillus at all studied periods except body weight and body weight gain at 3 and 1-3 wks of age, respectively. At the same manner, Houshmand et al. (2012) indicated that supplementing the diet with probiotics had no statistical influence on performance parameters of broilers. Latter authors added that the probiotic could highly improve FCR within the finisher period.

On the contrary, Chimote et al. (2009) found that adding probiotic to the diet improved $(p \leq 0.01)$ body weight and weight gain comparing with diets free of probiotic. Lacking of probiotic benefits in the current study might be due to the experimental conditions of our work. Birds were exposed to high relative humidity (RH \%) (around 80 to $85 \%$ ) besides high environmental temperature (around $33^{\circ} \mathrm{C}$ in some days in May). High RH and ambient temperature are stress factors which can prevent the quail response to supplemental probiotics. The contradicting results of the present work with some literature related to probiotic supplementation might be due to several factors affecting probiotic response as shown by Angel et al. (2005) where probiotics were shown to act efficiently on growth performance, in case of low nutrient-concentration 

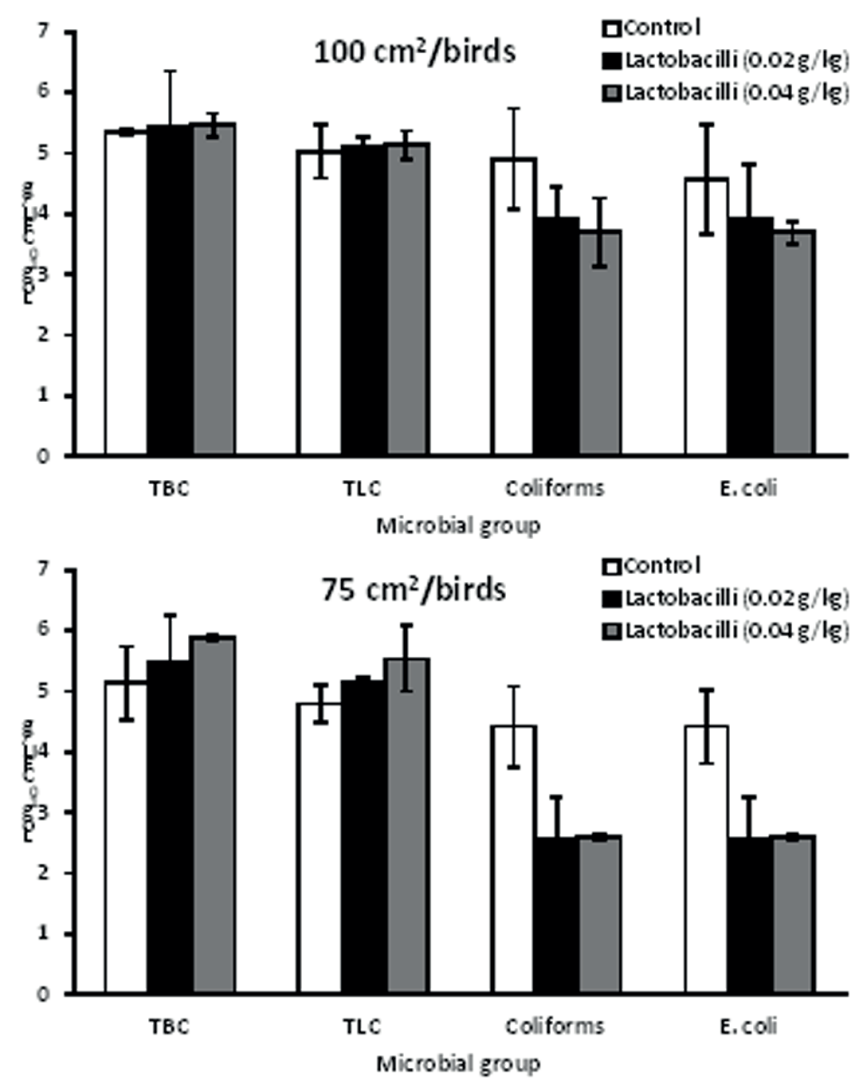

Figure 1 - Ileum microflora means [total bacterial count (TBC), total Lactobacilli count (TLC), Coliforms and E. coli] of Japanese quail as affected by stocking density (100 or $75 \mathrm{~cm}^{2} /$ birds) and dietary probiotic bacteria $(0.00,0.02$ and $0.04 \mathrm{~g} / \mathrm{kg})$ at 42 days of age.

was available in the diet which did not occur in the present study. In addition, the stability of the product, its viability, type and dose of preparation, flora composition in the host and the adherence to the epithelial tissue of the gastrointestinal tract and the specificity for the living host should be taken into consideration (Vargas-Rodriguez et al. 2013). In addition to, environment, management, bird characteristics and nutrition could affect the response of birds to probiotics. Rearing conditions are very important factors, particularly under hot conditions (Houshmand et al. 2012).

Our results regarding the impact of stocking density on quail growth are in accordance with those of Attia et al. (2012) who assured that elevating stocking density of quail from 12 to 24 birds per $2000 \mathrm{~cm}^{2}$ floor space reduced ( $p \leq 0.01$ ) body weight at 3 and 6 weeks of age in addition to weight gain through 4-6 and 1-6 weeks of the age. The same author attributed the reduction in live body weight due to the higher environmental temperature which resulted from the overcrowding which caused stress on quails. Similarly, Askar and Assaf (2004) attributed the undesired impacts of high stocking density on quail growth were resulted from the modification of the resting behavior due to the disturbances by the other birds. Growth performance of quail could also be negatively affected by the reduction of airflow around the bird, and a reduction in access to feeders and waterers (Feddes et al. 2002). In this regard, Abdel-Azeem (2010) found that live body weight, weight gain 

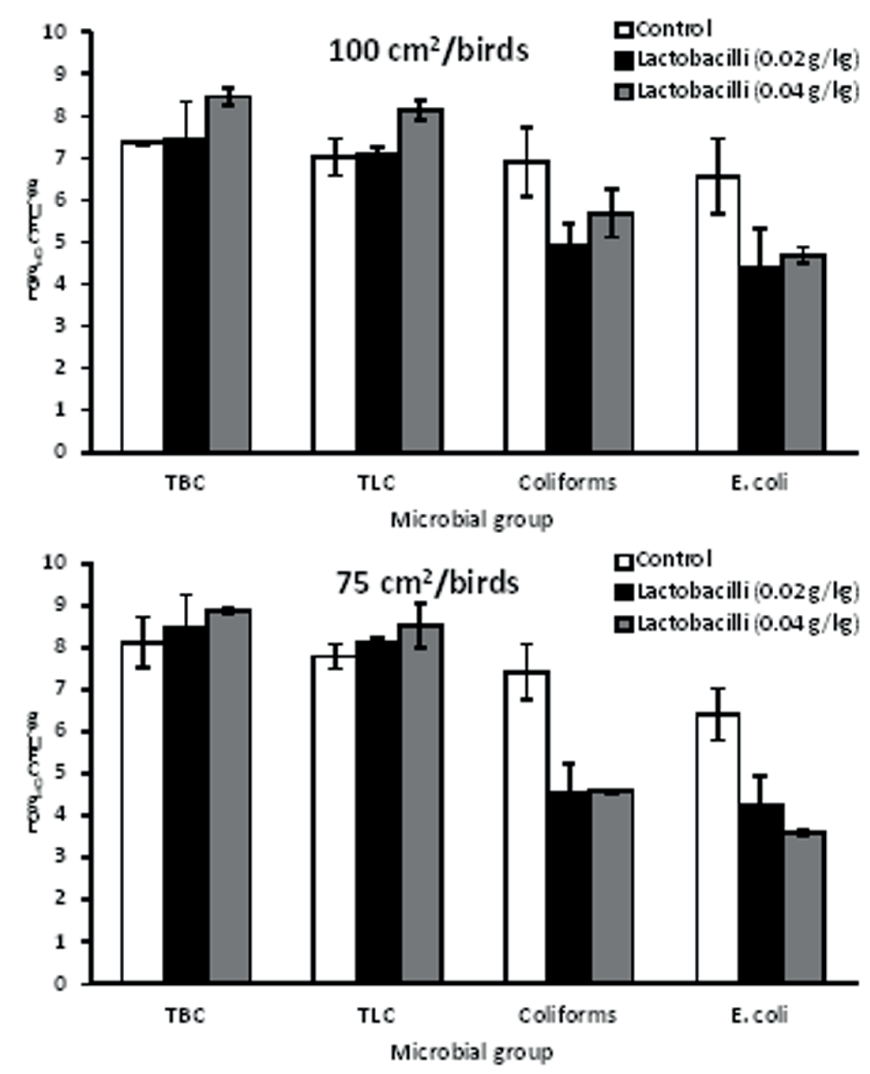

Figure 2 - Cecum microflora means [total bacterial count (TBC), total Lactobacilli count (TLC), Coliforms and E. coli] of Japanese quail as affected by stocking density ( 100 or $75 \mathrm{~cm}^{2} /$ birds) and dietary probiotic bacteria $(0.00,0.02$ and $0.04 \mathrm{~g} / \mathrm{kg})$ at 42 days of age.

and feed intake increased $(p \leq 0.05)$ when growing quail kept at $77 \mathrm{bird} / \mathrm{m}^{2}$, followed by a significant decreasing order for those kept at 100 birds $/ \mathrm{m}^{2}$ or those kept at $143 \mathrm{birds} / \mathrm{m}^{2}$. Similar results were also obtained by Karthiayini and Philomina (2014). El-Sagheer et al. (2012), Dhaliwal et al. (2008) and Houshmand et al. (2012) did not find statistical differences in either body weight or weight gain due to stocking density. As reported by VargasRodriguez et al. (2013), growth performance of broilers was not affected by the interaction between probiotic and stocking density.

\section{CARCASS TRAITS}

Chimote et al. (2009) reported that the dressing percentage was better $(p \leq 0.05)$ for quail consumed diet enriched with probiotic than those of the control. Also, Abdel-Azeem (2010) postulated that the quail kept at $77 \mathrm{bird} / \mathrm{m}^{2}$ recorded higher ( $p \leq$ $0.05)$ carcass organs weight than those kept under $100 \mathrm{bird} / \mathrm{m}^{2}$ or those reared at $143 \mathrm{bird} / \mathrm{m}^{2}$. The same author attributed that the increments of organs weight of quails, reared at $77 \mathrm{bird} / \mathrm{m}^{2}$, was due to the increased in body weight of this group as compared with the other groups (100 bird $/ \mathrm{m}^{2}$ or $143 \mathrm{bird} /$ $\mathrm{m}^{2}$ ). In broiler chicks, Feddes et al. (2002) found that carcass weight was lower when birds reared at $23.8 \mathrm{bird} / \mathrm{m}^{2}$ as compared with those reared at $17.9 ; 14.3$ and 11.9 birds $/ \mathrm{m}^{2}$, where those reared at $14.3 \mathrm{bird} / \mathrm{m}^{2}$ had the highest carcass weight. In addition, Hassanein (2011) found that stocking density reduced $(p \leq 0.05)$ weight of carcass. In 
line with present results, Seker et al. (2009) and Attia et al. (2012) demonstrated that carcass traits did not influence by stocking density. Furthermore, Vargas-Rodriguez et al. (2013) claimed that for hot carcass yield, the probiotic and density interaction was significant $(p \leq 0.05)$.

\section{LYMPHOID ORGANS}

In harmony with our findings, Houshmand et al. (2012) showed that the dietary addition of prebiotic did not affect spleen and bursa weights. Also, the same authors indicated that stocking density of broilers had no statistical effects on spleen and bursa weights. The stress factor of increasing stocking density could reduce lymphoid organs weights. In our study, birds fed diet supplemented with probiotic at $0.02 \mathrm{~g} / \mathrm{kg}$ of diet and kept at lower stocking density showed the highest spleen weight when compared with those of the other groups. Moreover, El-Gogary et al. (2015) found that stocking density did not affect lymphoid organs (Spleen, thymus and bursa of Fabricius) weight of broiler chicks.

\section{MICROBIOLOGICAL FINDINGS}

Minimizing the count of harmful microbes is always associated with better metabolism and growth of beneficial microorganisms that might had positive impact on the growth and retention of nutrients in the current study. The combination of these events (CFU of TLC with level $0.04 \mathrm{~g} / \mathrm{kg}$ and stocking density $100 \mathrm{~cm}^{2} /$ birds) favors colonization of TLC and declining coliforms and E. coli in the cecum and ileum. Results of the present study assured that dietary probiotic addition decreased the count of harmful microorganisms. Overall, the increase in the TLC population with ileal absorption surface in quail consumed diets with probiotic might be considered as an antibiotics alternative to improve population of ileal bacteria and stimulate tissue turnover at level of villus. So, it is essential to add natural like as probiotic to improve digestibility and bioavailability of nutrients (Chimote et al. 2009). Many reports assured the beneficial impacts of probiotics on growth traits (Ashour et al. 2015), intestinal microflora (Mountzouris et al. 2010), reducing the susceptibility to diseases, enhancing immunity function (Molnar et al. 2011), and improving carcass yield and quality (Bielecka et al. 2010). From the present results it could be concluded that the low $\left(100 \mathrm{~cm}^{2} /\right.$ bird $)$ stocking density was sufficient to give better growth of meattype quail. Dietary addition of probiotic to growing quail resulted in beneficial impacts. Moreover, higher $\left(75 \mathrm{~cm}^{2} /\right.$ bird $)$ stocking density with probiotic supplementation diminished the stressful effect of crowding of growing Japanese quail.

\section{AUTHOR CONTRIBUTIONS}

Khalid Mahrose, Mahmoud Alagawany and Mohamed Abd El-Hack designed and carried out the experimental trail. Samir Mahgoub performed lab analysis, the statistics and tabulated the data. Faten Attia wrote the draft paper. Mohamed Abd El-Hack revised and reviewed the manuscript.

\section{REFERENCES}

ABDEL-AZEEM FA. 2010. The influence of different stocking density and sex on productive performance and some physiological traits of Japanese quail. Egypt Poult Sci J 30: 203-227.

ABD EL-HACK ME, MAHGOUB SA, ALAGAWANY M AND ASHOUR EA. 2017. Improving productive performance and mitigating harmful emissions from laying hen excreta via feeding on graded levels of corn DDGS with or without Bacillus subtilis probiotic. J Anim Physiol Anim Nutr 101: 904-913.

ABD EL-HACK ME, MAHGOUB SA, ALAGAWANY M AND DHAMA K. 2015. Influences of dietary supplementation of antimicrobial cold pressed oils mixture on growth performance and intestinal microflora of growing Japanese quails. Inter J Pharmacol 11: 689-696.

ALAGAWANY M, ABD EL-HACK ME, ARIF M AND ASHOUR EA. 2016. Individual and combined effects of crude protein, methionine, and probiotic levels on laying 
hen productive performance and nitrogen pollution in the manure. Environ Sci Poll Res 23: 22906-22913.

ALAGAWANY M, ABD EL-HACK ME, FARAG MR, SACHAN S, KARTHIK K AND DHAMA K. 2018. The use of probiotics as eco-friendly alternatives for antibiotics in poultry nutrition. Environ Sci Poll Res 25: 10611-10618.

ANGEL R, DALLOUL RA AND DOERR J. 2005. Performance of broiler chickens fed diets supplemented with a direct-fed microbial. Poult Sci 84: 1222-1231.

ASHOUR EA, ABD EL-HACK ME AND OSMAN AO. 2015. Growth performance, carcass characteristics and blood serum biochemistry of broiler chickens fed different levels of dried whey. Inter J Curr Res Biosci Plant Biol 2: 1-8.

ASKAR AA AND ASSAF IM. 2004. Biological performance of growing Japanese quail as affected by stocking density and dietary protein level. J Agric Sci 29: 623-638.

ATTIA AI, MAHROSE KHM, ISMAIL IE AND ABOUKASEM DE. 2012. Response of growing Japanese quail raised under two stocking densities to dietary protein and energy levels. Egypt J Anim Prod 47: 159-166.

BIELECKA M, SMORAGIEWICZ W, SIWICKI AK, WOJCIK R, BIEDRZYCKA E, ORLOWSKI A, KASK S, JANKOWSKI J, KARSKA-WYSOCKI B AND HAM D. 2010. The effect of various probiotic strains or avilamycin feed additive on immune defense markers and acute-phase response to salmonella infection in chickens. Probiot Antimicrob Prot 2: 175-185.

BUIJS S, KEELING L, RETTENBACHER S, VAN POUCKE E AND TUYTTENS FAM. 2009. Stocking density effects on broiler welfare: Identifying sensitive ranges for different indicators. Poult Sci 88: 1536-1543.

CHIMOTE MJ, BARMASE BS, RAUT AS, DHOK AP AND KURALKAR SV. 2009. Effect of supplementation of probiotic and enzymes on performance of Japanese quails. Vet World 2: 219-220.

DUNCAN DB. 1955. Multiple Range and Multiple F-test. Biomet 11: 1-42.

EL-GOGARY MR, ISMAIL FSA AND EL-NADI MI. 2015. Effect of vitamin E supplementation and stocking density on broiler performance, carcass traits and histological responses of lymphoid organs. Asian J Poult Sci 9: 70-84.

EL-KHOLY MS, EL-HINDAWY MM, ALAGAWANY M, ABD EL-HACK ME AND EL-SAYED SAA. 2018. Use of acetylsalicylic acid as an allostatic modulator in the diets of growing Japanese quails exposed to heat stress. J Therm Biol 74: 6-13.

FEDDES JJR, EMMANUEL EJ AND ZUIDHOF MJ. 2002. Broiler performance, body weight variance, feed and water intake, and carcass quality at different stocking densities. Poult Sci 81: 774-779.

HASSANEIN HHM. 2011. Growth performance and carcass yield of broilers as affected by stocking density and enzymatic growth promoters. Asian J Poult Sci 5: 94-101.

HOUSHMAND M, AZHAR K, ZULKIFLI I, BEJO MH AND KAMYAB A. 2012. Effects of prebiotic, protein level, and stocking density on performance, immunity, and stress indicators of broilers. Poult Sci 91: 393-401

KARTHIAYINI K AND PHILOMINA PT. 2014. Probiotic supplementation in alleviating stress in broiler chicken. J Agric Vet Sci 7: 54-58.

MOLNAR AK, PODMANICZKY B, KURTI P, GLAVITS R, VIRAG G, SZABO Z AND FARKAS Z. 2011. Effect of different concentrations of bacillus subtilis on immune response of broiler chickens. Probiot Antimicrob Prot 3: 8-14.

MOUNTZOURIS KC, TSIRTSIKOS P, PALAMIDI I, ARVANITI A, MOHNL M, SCHATZMAYR G AND FEGEROS K. 2010. Effects of probiotic inclusion levels in broiler nutrition on growth performance, nutrient digestibility, plasma immunoglobulins, and caecal microflora composition. Poult Sci 89: 58-67.

NRC, NATIONAL RESEARCH COUNCIL. 1994. Nutrient Requirements of Poultry $9^{\text {th }}$ ed., National Academy of Science, Washington, DC., USA.

SEKER I, SELIM K AND METIN BA. 2009. Effect of group size on fattening performance, mortality rate, slaughter and carcass characteristics in Japanese quail (Coturnix Coturnix Japonica). J Anim Vet Adv 8: 688-693.

VARGAS-RODRÍGUEZ LM，DURÁN-MELÉNDEZ LA, GARCÍA-MASÍAS JA, ARCOS-GARCÍA JL, JOAQUÍN-TORRES BM AND RUELAS-INZUNZA MG. 2013. Effect of probiotic and population density on the growth performance and carcass characteristics in broiler chickens. Inter J Poult Sci 12: 390-395. 